(СЮ. О. Риберт

Львівський національний медичний університет імені Данила Галицького

\title{
Аналіз ефективності лікування пацієнтів із суглобовими скронево-нижньощелепними розладами
}

Резюме. Суглобові форми скронево-нижньощелепних розладів (компресія біламінарної зони, зміщення меніска, гіпермобільність, артрити, артрози) поєднуються із розвиненими формами зубощелепної патології, які призводять до порушень функціональної оклюзії. Поєднані форми оклюзійної патології характерні для пацієнтів старшого віку (після 40 років), разом з тим, як ортодонтична патологія характерна для пацієнтів 20-40 років. Складність поєднаної патології скронево-нижньощелепного суглоба (СНЩС) й оклюзії вимагає ретельної діагностики, опрацювання детального плану лікування від санації порожнини рота до застосування різних за типом дій оклюзійних шин з обов’язковим завершенням лікування протетичною реабілітацією ортопедичними конструкціями для відтворення функціональної оклюзії. Представлено аналіз результатів лікування пацієнтів із поєднанням суглобової форми скронево-нижньощелепних розладів і оклюзійною патологією із застосуванням оклюзійної терапії, сплінтлайн-терапії та на завершальному етапі різних типів ортопедичних конструкцій для стабілізації функціональної оклюзії. Аналіз базується на порівнянні аксіограм до і після завершення лікування.

Ключові слова: скронево-нижньощелепні розлади, аксіографія, лікування.

\section{Ю. А. Рыберт}

Львовский национальный медицинский университет имени Данила Галицкого

\section{Анализ эффективности лечения пациентов с суставными височно-нижнечелюстными расстройствами}

Резюме. Суставные формы височно-нижнечелюстных расстройств (компрессия биламинарной зоны, смещение мениска, гипермобильность, артриты, артрозы) часто сочетаются с разными формами зубочелюстной патологии, которые приводят к нарушениям функциональной окклюзии. Сочетанные формы окклюзионной потологии характерны пациентам старшего возраста (после 40 лет), в то время, как ортодонтическая патология характерна для пациентов 20-40 лет. Сложность сочетанной патологии височно-нижнечелюстного суглоба (ВНЧС) и окклюзии требует тщательной диагностики, выработки детального плана лечения от санации полости рта до применения различных по типу действия окклюзийных шин с обязательным завершением лечения протетической реабилитацией ортопедическими конструкциями для востановления и стабилизация функциональной окклюзии. Представлен анализ результатов лечения пациентов с сочетанием суставной формы височнонижнечелюстных расстройств и окклюзионной патологией с применением окклюзионной терапии, сплинтлайн-терапии и на завершающем этапе различных типов ортопедических конструкций для стабилизации функциональной окклюзии. Анализ базируется на сравнении аксиограм до и после завершения лечения.

Ключевые слова: височно-нижнечелюстные расстройства, аксиография, лечение.

\section{Yu. O. Rybert}

Danylo Halytskyi Lviv National Medical University

\section{Effectiveness analysis of the treatment of patients with articular temporomandibular disorders}

Summary. Articular forms of temporomandibular disorder (compression of bilaminar region, displacement of meniscus, hypermobility, arthritis, arthrosis) combine with advanced forms of dental pathology leading to disturbances of functional occlusion. The comorbidities of occlusal pathology are characteristic of older pa- 


\section{Ортопедична стоматологія}

tients (over 40), while the orthodontic pathology is characteristic of patients aged 20-40.

The complexity of comorbidity of TMJ and occlusal pathology requires a thorough diagnostic study, detailed treatment plan that ranges from dental health to the application of occlusal splints of different types of action with mandatory completion of treatment with prosthetic rehabilitation using prosthetic restorations to restore functional occlusion. The analysis of results of treatment of patients with comorbidities of temporomandibular disorders and occlusal pathology using occlusal therapy, splintline therapy, and various types of prosthetic restorations at the final stage to stabilize functional occlusion is presented. The analysis is based on the comparison of axiograms before and after the treatment.

Key words: temporomandibular disorders, axiography, treatment.

Вступ. Суглобові розлади СНщС у поєднані 3 оклюзійною патологією із точки зору діагностики і лікування відносяться до складних форм суглобової дисфункції $[2,3,5]$.

У таких випадках, крім діагностики самих суглобових розладів із застосуванням клінічних і додаткових, переважно променевих методів дослідження, необхідне ретельне визначення стану функціональної оклюзії методами оклюзіографії з наступним аналізом у індивідуально налаштованому артикуляторі $[1,4,6,7]$.

Підбір оклюзійної шини повинен бути суто індивідуальний, а іï конструкція базуватися на налаштованому на індивідуальну функцію в артикуляторі [1,7].

Результат оклюзійної терапії у зв’язку з перебудовою міостатичного рефлексу та оклюзійних співвідношень з урахування різних за видами оклюзіопатій у пацієнтів потребує в подальшому обов'язкового протезування різними типами ортопедичних конструкцій, які б забезпечили реконструкцію і стабілізацію функціональної оклюзії [8, 9].

Мета дослідження полягає в оцінці ефективності лікування пацієнтів 3 суглобовими скронево-нижньощелепними розладами із застосуванням оклюзійних шин та на завершальному етапі різних варіантів ортопедичних конструкцій для стабілізації функціональної оклюзії.

Матеріали і методи. Об’єктом дослідження були діагностовані суглобові скронево-нижньощелепні розлади у 47 пацієнтів, із них 24 чоловіки та 23 жінки з різними варіантами оклюзійної патології до та після комплексного лікування.

Кожен пацієнт 3 артропатією, залежно від iï форми та стану зубощелепного комплексу, потребував суто індивідуального підходу щодо комплексного лікування, яке будувалося на основі ретельного клінічного аналізу, аналізу додаткових методів дослідження, які включали панорамну рентгенографію, ультразвукове обстеження СНщС і жувальних м’язів, за пока- занням МРТ-дослідження, артрографію зі застосуванням Denar Cadiax Compact 2 (Gamma Dental) (Австрія), аналіз функціональної оклюзії в індивідуально налаштованому артикуляторі за отриманими артрограмами та індивідуального підходу до вибору оклюзійної шини.

Кінцевий вибір ортопедичної конструкції залежав від досягнутого результату оклюзіотерапії та сплінтлайн-терапії і стану зубощелепного комплексу після санації (видалення зубів за показанням, пародонтальна хірургія, ендодонтичне та відновне лікування зубів, що залишилися, тощо).

Результати досліджень та їх обговорення. Серед обстежених 47 пацієнтів із поєднанням суглобової патології СНЩС та діагностованими оклюзіопатіями при аналізі артропатій виявлено, що зміщення меніска діагностовано у 70,2 \% обстежених пацієнтів, компресія біламінарної зони - у 12,8 \%, артроз - у 10,6 \%, гіпермобільність - у 6,4 \% та артрити - у 4,4 \% обстежених. У двох пацієнтів діагностовано зміщення меніска плюс артроз і компресію біламінарної зони плюс гіпермобільність відповідно.

У процесі лікування 10 пацієнтам зі зміщенням меніска проведено оклюзіопатію 3 наступним раціональним протезуванням незмінними конструкціями зубних протезів із реконструкцією функціональної оклюзії, 7 пацієнтам проведено оклюзіотерапію 3 наступним відновленням функціональної оклюзії покривними протезами з фіксацією на телескопічних коронках. Трьом пацієнтам після оклюзіотерапії відновлення функціональної оклюзії досягнуто бюгельним протезуванням.

Двом пацієнтам після оклюзіотерапії відновлення функціональної оклюзії здійснено в комбінації незнімних протезів на одній щелепі з покривними протезами на телескопічних коронках на іншій, а у двох пацієнтів нормалізації функції СНЩС вдалося досягнути відновленням функціональної оклюзії тільки за рахунок за- 
стосування покривних протезів на телескопічних коронках під контролем аксіографії і постановки зубів в індивідуальному артикуляторі.

У випадках наявності ортодонтичної патології у пацієнтів зі зміщенням меніска, крім оклюзіотерапії, застосовано сплінтлайн-терапію у двох пацієнтів. У двох інших пацієнтів, крім оклюзіопатії і сплінтлан-терапії ортодонтичне лікування завершилося раціональним протезуванням під контролем аксіографії.

Тільки сплінтлайн-терапія дала позитивний лікувальний ефект у одного пацієнта 3 ортодонтичною патологією.

В одного пацієнта старшого віку оклюзіотерапія була завершена постійною оклюзійною шиною.

У двох випадках за наявності в пацієнтів розвиненої форми парадонтиту проведено пародонтальну хірургію з наступною оклюзіотерапією, яка завершилася в одному випадку бюгельним протезуванням.

В одного пацієнта зі зміщенням меніска застосована пряма нормалізація оклюзії з наступними оклюзіотерапією і протезуванням бюгельними протезами.

Серед п’яти пацієнтів із компресією біламінарної зони в одного з них досягнуто позитивного лікувального ефекту тільки відновленням функціональної оклюзії покривними протезами на телескопічних коронках. У інших чотирьох пацієнтів застосована оклюзіотерапія 3 наступним раціональним протезуванням в одного і телескопічним протезуванням у трьох.
При гіпермобільності у двох пацієнтів 3 ортодонтичною патологією позитивний ефект досягнуто комбінацією оклюзіотерапії із сплінтлайн-терапією.

У чотирьох пацієнтів з артрозом СНЩС ортопедичні заходи включали оклюзіотерапію в одного, оклюзіотерапію і раціональне протезування в одного, оклюзіотерапію з постійною оклюзійною шиною у одного і протезування на телескопічних коронках також в одного.

При артриті СНЩС ортопедична частина лікування у двох пацієнтів включала тільки оклюзіотерапію.

У двох пацієнтів із комбінованою патологією СНЩС компресія біламінарної зони плюс гіпермобільність та зміщення меніска плюс артроз застосована тільки оклюзіотерапія.

Ефективність проведеного лікування пацієнтів із суглобовими розладами визначена шляхом порівняння аксіограм до і після лікування з їх статистичним опрацюванням.

На повторну аксіографію через 12 місяців після завершення повного курсу реабілітації з 29 первинних пацієнтів, яким попередньо була зроблена аксіографія, з'явилася 21 особа.

Порівняльний аналіз показників рухів суглобових головок нижньої щелепи у пацієнтів з артропатіями до і після лікування наведений у таблиці 1.

У результаті проведеного комплексу лікувальних заходів за результатами, наведеними в таблиці 1, кількість пацієнтів 3 нормальними показниками за показником «протрузія-

Таблиця 1. Амплітуда рухів суглобових головок нижньої щелепи у пацієнтів з артропатіями до і після лікування

\begin{tabular}{|c|c|c|c|c|c|c|c|c|c|c|c|c|c|c|c|c|c|}
\hline \multirow{3}{*}{\multicolumn{2}{|c|}{ Патологія }} & \multirow{3}{*}{ 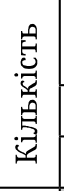 } & \multicolumn{5}{|c|}{$\begin{array}{c}\text { Протрузія/ретрузія } \\
\text { (n=8-12 мм) }\end{array}$} & \multicolumn{5}{|c|}{$\begin{array}{l}\text { Медіотрузія } \\
(\mathrm{n}=10-14 \mathrm{Mм})\end{array}$} & \multicolumn{5}{|c|}{$\begin{array}{c}\text { Відкриття/закриття рота } \\
\text { (n =10-14 мм) }\end{array}$} \\
\hline & & & \multicolumn{2}{|c|}{1 бік } & \multicolumn{2}{|c|}{2 боки } & \multirow{2}{*}{$\mathrm{n}$} & \multicolumn{2}{|c|}{1 бік } & \multicolumn{2}{|c|}{2 боки } & \multirow{2}{*}{$\mathrm{n}$} & \multicolumn{2}{|c|}{1 бік } & \multicolumn{2}{|c|}{2 боки } & \multirow{2}{*}{$\mathrm{n}$} \\
\hline & & & $<\mathrm{n}$ & $>\mathrm{n}$ & $<\mathrm{n}$ & $>\mathrm{n}$ & & $<\mathrm{n}$ & $>n$ & $<\mathrm{n}$ & $>\mathrm{n}$ & & $<\mathrm{n}$ & $>n$ & $<\mathrm{n}$ & $>\mathrm{n}$ & \\
\hline \multirow{4}{*}{$\begin{array}{c}\text { До } \\
\text { лікування }\end{array}$} & $\begin{array}{l}\text { Артро- } \\
\text { патія }\end{array}$ & \multirow{4}{*}{29} & 11 & 3 & 7 & 0 & 8 & 11 & 3 & 11 & 3 & 1 & 7 & 4 & 14 & 1 & 3 \\
\hline & \multirow{3}{*}{$\begin{array}{l}\text { (\%) у цій } \\
\text { групі }\end{array}$} & & 38,0 & 10,3 & 24,1 & 0,0 & \multirow{3}{*}{27,6} & 38,0 & 10,3 & 38,0 & 10,3 & \multirow{3}{*}{3,4} & 24,2 & 13,8 & 48,3 & 3,4 & \multirow{3}{*}{10,3} \\
\hline & & & \multicolumn{2}{|c|}{48,3} & \multirow{2}{*}{\multicolumn{2}{|c|}{24,1}} & & \multicolumn{2}{|c|}{48,3} & \multicolumn{2}{|c|}{48,3} & & \multicolumn{2}{|c|}{38,0} & \multicolumn{2}{|c|}{51,7} & \\
\hline & & & \multicolumn{2}{|c|}{72,4} & & & & \multicolumn{4}{|c|}{96,6} & & \multicolumn{4}{|c|}{89,7} & \\
\hline \multirow{4}{*}{$\begin{array}{c}\text { Після } \\
\text { лікування }\end{array}$} & $\begin{array}{c}\text { Артро- } \\
\text { патія }\end{array}$ & \multirow{4}{*}{21} & 3 & 1 & 4 & 0 & 13 & 3 & 2 & 6 & 2 & 8 & 2 & 1 & 5 & 1 & 12 \\
\hline & \multirow{3}{*}{$\begin{array}{l}\text { (\%) у цій } \\
\text { групі }\end{array}$} & & 14,2 & 4,8 & 19,0 & 0,0 & \multirow{3}{*}{62,0} & 14,3 & 9,5 & 28,6 & 9,5 & \multirow{3}{*}{38,1} & 9,5 & 4,8 & 23,8 & 4,8 & \multirow{3}{*}{57,1} \\
\hline & & & & 0 & 19, & & & & 8 & 38 & 1 & & & 1,3 & 28 & 6 & \\
\hline & & & & 38 & & & & & & $9 \# \#$ & & & & & $9 \# \#$ & & \\
\hline
\end{tabular}

Примітка. Порівняння з групою до лікування: \# - p<0,05; \#\# - p<0,01. 
ретрузія» сягнула 62,0 проти 27,6 \% до лікування $(\mathrm{p}<0,05)$, тобто число пацієнтів 3 від’ємними показниками зменшилося з 72,4 до лікування до 38,0 \% після лікування у 1,9 раза $(\mathrm{p}<0,05)$.

За показником «медіотрузія» позитивні нормативні показники, як наслідок лікування, отримані у $38,1 \%$ пацієнтів проти $3,4 \%$ до лікування, тобто у 11,2 раза $(\mathrm{p}<0,01)$.

Відбулися позитивні зміни і за показником «відкриття-закриття рота». Так, нормативні показники після лікування були виявлені у 57,1 \% пацієнтів проти 10,4 \% до лікування, тобто у 5,6 раза $(\mathrm{p}<0,01)$. Відповідно відбулися зменшення числа пацієнтів зі зміненими по- казниками з 89,7 \% до лікування до 42,9 \% після лікування $(\mathrm{p}<0,01)$.

Порівняльний аналіз показників розходження траєкторії руху суглобових головок нижньої щелепи у пацієнтів з артропатіями до і після лікування наведений у таблиці 2.

Результати дослідження, представлені у таблиці 2, засвідчують, що за показником «протрузія-ретрузія» кількість пацієнтів із нормативними показниками після лікування сягнула 90,5 проти 75,9 \% до лікування (p<0,05). Відповідно число пацієнтів зі зміненими показниками зменшилося з 24,1 \% до лікування до 9,5 \% після лікування у 2,5 раза (p<0,05).

Таблищя 2. Аналіз розходження траєкторій руху суглобових головок нижньої щелепи у пацієнтів з артропатіями до і після лікування

\begin{tabular}{|c|c|c|c|c|c|c|c|c|c|c|c|}
\hline \multirow{3}{*}{\multicolumn{2}{|c|}{ Патологія }} & \multirow{3}{*}{ 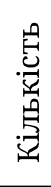 } & \multicolumn{3}{|c|}{ Протрузія/ретрузія } & \multicolumn{3}{|c|}{ Медіотрузія } & \multicolumn{3}{|c|}{ Відкриття/закриття рота } \\
\hline & & & \multirow{2}{*}{\begin{tabular}{|c} 
на 1 боці \\
$>\mathrm{n}$ \\
\end{tabular}} & \multirow{2}{*}{$\begin{array}{c}32 \text { 2-x } \\
\text { боків } \\
>n\end{array}$} & \multirow{2}{*}{$\mathrm{n}$} & на 1 боці & з 2-х боків & \multirow{2}{*}{$\mathrm{n}$} & на 1 боці & $\begin{array}{l}32-\mathrm{x} \\
\text { - }\end{array}$ & \multirow{2}{*}{$n$} \\
\hline & & & & & & $>\mathrm{n}$ & $>\mathrm{n}$ & & $>\mathrm{n}$ & $>\mathrm{n}$ & \\
\hline \multirow{3}{*}{$\begin{array}{c}\text { До } \\
\text { лікування }\end{array}$} & Артропатія & \multirow{3}{*}{29} & 4 & 3 & 22 & 13 & 8 & 8 & 14 & 5 & 10 \\
\hline & \multirow{2}{*}{$\begin{array}{c}\text { (\%) у цій } \\
\text { групі }\end{array}$} & & 13,8 & \multirow[t]{2}{*}{10,3} & \multirow{2}{*}{75,9} & 44,8 & 27,6 & \multirow{2}{*}{27,6} & 48,3 & 17,2 & \multirow{2}{*}{34,5} \\
\hline & & & 24 & & & \multicolumn{2}{|c|}{72,4} & & \multicolumn{2}{|c|}{65,5} & \\
\hline \multirow{3}{*}{$\begin{array}{c}\text { Після } \\
\text { лікування }\end{array}$} & Артропатія & \multirow{3}{*}{21} & 0 & 2 & 19 & 3 & 5 & 13 & 4 & 2 & 15 \\
\hline & (\%) у цій & & 0,0 & 9,5 & \multirow{2}{*}{$90,5 \#$} & 14,3 & 23,8 & \multirow{2}{*}{$61,9 \#$} & 19,0 & 9,6 & \multirow{2}{*}{ 71,4\# } \\
\hline & групі & & \multicolumn{2}{|c|}{$9,5 \#$} & & \multicolumn{2}{|c|}{$38,1 \#$} & & \multicolumn{2}{|c|}{$28,6 \#$} & \\
\hline
\end{tabular}

Примітка. Порівняння з групою «до лікування»: \# - p<0,05.

За показником «медіотрузія» число пацієнтів із нормативним показником після лікування дорівнювало 61,9 проти 27,6 \% до лікування ( $<<0,05)$, що відповідно зменшило число пацієнтів зі зміненими показниками до лікування з 72,4 до 38,9 \% після лікування у 1,9 раза $(\mathrm{p}<0,05)$.

Позитивні результати лікування досягнули і за показником «відкриття-закриття рота». Так, число пацієнтів 3 нормативними показниками до лікування складало 34,5, а після лікування 71,4 \% ( $<0,05)$, тобто кількість пацієнтів 3 від’ємними показниками знизилася з 65,5 до лікування до $28,6 \%$ після лікування у 2,3 раза ( $<<0,05)$.

Порівняльний аналіз показників «початоккінець» рухів суглобових головок нижньої щелепи пацієнтів з артропатіями до і після лікування наведений у таблиці 3.

За результатами проведеної оцінки показників «протрузія-ретрузія» у пацієнтів 3 артропатіями до і після лікування виявлено, що кількість пацієнтів з нормативними показниками після лікування дорівнювала 47,6 проти 37,9 \% до лікування (p<0,05), тобто збільшилася всього на $10 \%$.

За показником «медіотрузія» число пацієнтів 3 нормативним показниками після лікування дорівнювало 66,7 проти 27,6 \% до лікування $(\mathrm{p}<0,05)$, тобто кількість пацієнтів 3 від’ємними показниками після лікування зменшилася з 72,4 до лікування до 33,3 \% після лікування у 2,2 раза $(\mathrm{p}<0,05)$.

За показником "відкриття-закриття рота" після проведеного лікування число пацієнтів із нормативними показниками дорівнювало 61,9 проти $24,1 \%$ після лікування, тобто кількість пацієнтів 3 нормативними показниками аксіографії «відкриття-закриття рота» збільшилася у 2,7 раза $(\mathrm{p}<0,05)$.

Порівняльний аналіз показників кута сагітального суглобового шляху (КССШ) та кута трансверзального сагітального шляху (КТСШ) у пацієнтів з артропатіями до і після лікування наведений у таблиці 4.

3а результатами, наведеними у таблиці 4, виявлено, що після проведеного лікування 
таблиця 3. Аналіз початку/кінця руху суглобових головок нижньої щелепи у пацієнтів з артропатіями до і після лікування $(\mathrm{n}<0,2)$

\begin{tabular}{|c|c|c|c|c|c|c|c|c|c|c|c|}
\hline \multirow{3}{*}{\multicolumn{2}{|c|}{ Патологія }} & \multirow{3}{*}{ 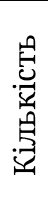 } & \multicolumn{3}{|c|}{ Протрузія/ретрузія } & \multicolumn{3}{|c|}{ Медіотрузія } & \multicolumn{3}{|c|}{$\begin{array}{c}\text { Відкриття/закриття } \\
\text { рота } \\
\end{array}$} \\
\hline & & & 1 бік & 2 боки & \multirow{2}{*}{$\mathrm{n}$} & 1 бік & 2 боки & \multirow{2}{*}{$\mathrm{n}$} & 1 бік & 2 боки & \multirow{2}{*}{$\mathrm{n}$} \\
\hline & & & $>\mathrm{n}$ & $>\mathrm{n}$ & & $>\mathrm{n}$ & $>\mathrm{n}$ & & $>\mathrm{n}$ & $>\mathrm{n}$ & \\
\hline \multirow{3}{*}{$\begin{array}{c}\text { До } \\
\text { лікування }\end{array}$} & Артропатія & \multirow{3}{*}{29} & 3 & 15 & 11 & 10 & 11 & 8 & 5 & 17 & 7 \\
\hline & \multirow{2}{*}{$\begin{array}{l}\text { (\%) у цій } \\
\text { групі }\end{array}$} & & 10,3 & 51,8 & \multirow{2}{*}{37,9} & 34,5 & 37,9 & \multirow{2}{*}{27,6} & 17,2 & 58,7 & \multirow{2}{*}{24,1} \\
\hline & & & \multicolumn{2}{|c|}{62,1} & & \multicolumn{2}{|c|}{72,4} & & \multicolumn{2}{|c|}{75,9} & \\
\hline \multirow{3}{*}{$\begin{array}{c}\text { Після } \\
\text { лікування }\end{array}$} & Артропатія & \multirow{3}{*}{21} & 3 & 8 & 10 & 2 & 5 & 14 & 0 & 8 & 13 \\
\hline & (\%) у цій & & 14,3 & 38,1 & \& & 9,5 & 23,8 & \multirow{2}{*}{$66,7 \#$} & 0,0 & 38,1 & \multirow{2}{*}{$61,9 \#$} \\
\hline & групі & & \multicolumn{2}{|c|}{$52,4 \#$} & $4 /, 0 \#$ & \multicolumn{2}{|c|}{$33,3 \#$} & & \multicolumn{2}{|c|}{$38,1 \#$} & \\
\hline
\end{tabular}

Примітка. Порівняння з групою «до лікування»: \# - p<0,05.

нормативні показники КССШ були досягнуті у 95,2 \% пацієнтів проти 75,9 \% до лікування (p<0,05), що дозволило знизити число пацієнтів із від’ємними показниками 324,3 \% до лікування до 4,8 \% після лікування у 5 разів $(\mathrm{p}<0,05)$.

Нормативні показники кута трансверзального суглобового шляху при «протрузї-ретрузії у пацієнтів до лікування були виявлені тільки у 3,4 \% осіб. У результаті проведеного лікування досягти нормалізації цього показник вдалося у 52,4 \% обстежених, тобто у 15,4 раза $(\mathrm{p}<0,01)$.

Нормативні показники КТСШ при «медіотрузії до лікування були виявлені у 20,7 \% пацієнтів, а після лікування число хворих із нор- мативними показниками дорівнювало 66,7 \%, тобто збільшилося у 3,2 раза $(\mathrm{p}<0,01)$.

Нормативні показники КТСШ при «відкритті-закритті рота" у пацієнтів з артропатіями до лікування взагалі не були виявлені, проте після лікування число пацієнтів із нормативними показниками дорівнювало 47,6 \% (p<0,01). Порівняльний аналіз якісної оцінки аксіограм у пацієнтів з артропатіями до і після лікування наведений у таблиці 5.

За результатами проведеного дослідження, виявлено, що, якщо кількість пацієнтів при артропатіях за оптимальною якістю артрограм до лікування склала 10,3 \%, то після лікування їх число збільшилося до $38,1 \%$ (p<0,05), а кількість пацієнтів з поганою якістю зменши-

таблищя 4. Аналіз кута сагітального суглобового шляху (КССШ) та кута трансверзального суглобового шляху (КТСШ) у пацієнтів з оклюзіопатіями до і після лікування

\begin{tabular}{|c|c|c|c|c|c|c|c|c|c|c|c|c|c|c|c|c|c|c|c|c|c|c|}
\hline \multirow{4}{*}{\multicolumn{2}{|c|}{ Патологія }} & \multirow{4}{*}{ 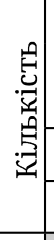 } & \multirow{2}{*}{\multicolumn{5}{|c|}{ КССШ $\mathrm{n}=(2$}} & \multicolumn{15}{|c|}{ КТСШ $\mathrm{n}=\left(5-20^{\circ}\right)$} \\
\hline & & & & & & & & \multicolumn{5}{|c|}{ протрузія/ретрузія } & \multicolumn{5}{|c|}{ медіотрузія } & \multicolumn{5}{|c|}{$\begin{array}{c}\text { відкриття/закриття } \\
\text { рота }\end{array}$} \\
\hline & & & \multicolumn{2}{|c|}{1 бік } & \multicolumn{2}{|c|}{2 боки } & \multirow{2}{*}{$\mathrm{n}$} & \multicolumn{2}{|c|}{1 бік } & \multicolumn{2}{|c|}{2 боки } & \multirow{2}{*}{$\mathrm{n}$} & \multicolumn{2}{|c|}{1 бік } & \multicolumn{2}{|c|}{2 боки } & \multirow{2}{*}{$\mathrm{n}$} & \multicolumn{2}{|c|}{1 бік } & \multicolumn{2}{|c|}{2 боки } & \multirow{2}{*}{$n$} \\
\hline & & & $<\mathrm{n}$ & $>\mathrm{n}$ & $<\mathrm{n}$ & $>\mathrm{n}$ & & $<\mathrm{n}$ & $>\mathrm{n}$ & $<\mathrm{n}$ & $>\mathrm{n}$ & & $<\mathrm{n}$ & $>\mathrm{n}$ & $<\mathrm{n}$ & $>\mathrm{n}$ & & $<\mathrm{n}$ & $>\mathrm{n}$ & $<\mathrm{n}$ & $>\mathrm{n}$ & \\
\hline \multirow{4}{*}{$\begin{array}{c}\text { До } \\
\text { ліку- } \\
\text { вання }\end{array}$} & $\begin{array}{l}\text { Оклюзіо- } \\
\text { патія }\end{array}$ & & 0 & 3 & 1 & 0 & 24 & 9 & 1 & 18 & 0 & 0 & 8 & 4 & 6 & 0 & 10 & 7 & 3 & 18 & 0 & 0 \\
\hline & & 28 & 0,0 & 10,7 & 3,6 & 0,0 & \multirow{3}{*}{85,7} & 32,1 & 3,6 & 64,3 & 0,0 & \multirow{3}{*}{0,0} & 28,6 & 14,3 & 21,4 & 0,0 & \multirow{3}{*}{35,7} & 25,0 & 10,7 & 64,3 & 0,0 & \multirow{3}{*}{0,0} \\
\hline & $\begin{array}{c}\text { у цій групі } \\
\text { (контрольна }\end{array}$ & & 10 & 0,7 & 3 , & & & 35 , & & 64, & & & 42 & 9 & 21, & & & 35 , &, 7 & 64 & 4,3 & \\
\hline & група) & & \multicolumn{4}{|c|}{14,3} & & \multicolumn{4}{|c|}{100,0} & & \multicolumn{4}{|c|}{64,3} & & \multicolumn{4}{|c|}{100,0} & \\
\hline \multirow{4}{*}{$\begin{array}{c}\text { Після } \\
\text { ліку- } \\
\text { вання }\end{array}$} & $\begin{array}{l}\text { Оклюзіо- } \\
\text { патія }\end{array}$ & \multirow{4}{*}{13} & 0 & 0 & 1 & 0 & 12 & 2 & 0 & 6 & 0 & 5 & 2 & 0 & 3 & 0 & 8 & 2 & 0 & 7 & 0 & 4 \\
\hline & $(\%)$ & & 0,0 & 0,0 & 7,7 & 0,0 & & 15,4 & 0,0 & 46,1 & 0,0 & & 15,4 & 0,0 & 23,1 & 0,0 & & 15,4 & 0,0 & 53,8 & 0,0 & \\
\hline & $\begin{array}{c}\text { у цій групі } \\
\text { (контрольна }\end{array}$ & & & 1,0 & 7 , & & 92,3 & 15 , & & 46 , & & $38,5 \#$ & & 5,4 & 23 & & 61,5 & 15 , &, 4 & 53 & 3,8 & $30,8 \#$ \\
\hline & група) & & & 7,7 & & & & & 61 & & & & & 38 & 3,5 & & & & 69, & $2 \#$ & & \\
\hline
\end{tabular}

Примітка. Порівняння з групою «до лікування»: \# - p<0,05; \#\# - p<0,01. 
таблищя 5. Якість аксіограм у пацієнтів з артропатіями до і після лікування

\begin{tabular}{|c|c|c|c|c|c|}
\hline \multirow{2}{*}{\multicolumn{2}{|c|}{ Патологія }} & \multirow{2}{*}{ Кількість } & \multicolumn{3}{|c|}{ Якість } \\
\hline & & & отимальна & середня & погана \\
\hline \multirow{2}{*}{ До лікування } & Артропатія & \multirow{2}{*}{29} & 3 & 15 & 11 \\
\hline & (\%) у цій групі & & 10,3 & 51,7 & 38,0 \\
\hline \multirow{2}{*}{$\begin{array}{c}\text { Після } \\
\text { лікування }\end{array}$} & Артропатія & \multirow{2}{*}{21} & 8 & 11 & 2 \\
\hline & (\%) у цій групі & & $38,1 \#$ & 52,4 & $9,5 \#$ \\
\hline
\end{tabular}

Примітка. Порівняння з групою «до лікування»: \# - p<0,05; \#\# - p<0,01.

лася 3 38,0 \% до лікування до 9,5 \% після лікування $(\mathrm{p}<0,05)$ при збереженні кількості пацієнтів із середньою якістю аксіограм до і після лікування - 51,7 проти 52,4 \% відповідно.

Вважаємо, що ці зміни відбулися за рахунок «переміщення» частини пацієнтів із групи 3 «середньої якості» до групи 3 «оптимальної якості», а з групи з «поганої якості» у групу «середньої якості», як результат проведеного лікування.

Висновки. Суглобові форми скронево-нижньощелепних розладів (компресія біламінарної зони, зміщення меніска, гіпермобільність, артрити, артрози) поєднуються із розвинени-

\section{Список літератури}

1. Біда В. І. Ортопедичне лікування хворих із оклюзійно-артикуляційним синдромом дисфункції скронево-нижньощелепного суглоба / В. І. Біда, С. М. Клочан // Український стоматологічний альманах. - 2012. - № 3. - С. 22-24.

2. Макєєв В. Ф. Оклюзійно-артикуляційна концепція розвитку синдрому м'язово-суглобової дисфункції в пацієнтів з патологією оклюзії / В. Ф. Макєєв, Ю. О. Риберт, Ю. О. Кінаш // Український стоматологічний альманах. - 2-14. - 2014. - № 4. - С. 70-75.

3. Макєєв В. Ф. Частота та розподіл за нозологічними формами скронево-нижньощелепних розладів / В. Ф. Макєєв, У. Д. Телішевська, Р. В. Куліченко // Новини стоматології. - 2009. - № 2. - С. 48-51.

4. Особливості диференціальної діагностики скронево-нижньощелепних розладів за клінічними і рентгенологічними ознаками / В. Ф. Макєєв, У. Д. Телішевська, Р. В. Куліченко, М. І. Заверуха // Український стоматологічний альманах. - 2011. № 1. - С. 69-74.

5. Манфредини Д. Височно-нижнечелюстные расстройства. Современные концепции диагностики и лечения / Д. Манфредини [пер. с англ. А. Остров- ми формами зубощелепної патології, які призводять до порушень функціональної оклюзіі.

Поєднані форми оклюзійної патології характерні для пацієнтів старшого віку (після 40 років), разом $з$ тим, як ортодонтична патологія характерна для пацієнтів 20-40 років.

Складність поєднаної патології сНщс i оклюзії вимагає ретельної діагностики, опрацювання детального плану лікування від санації порожнини рота до застосування різних за типом дій оклюзійних шин з обов'язковим завершенням лікування протетичною реабілітацією ортопедичними конструкціями для відтворення функціональної оклюзії. ский и др.]. - Научн. ред. М. Антоник и др. - (London, Berlin,Chicago, Tokyo, Barselona, Istanbul, Milan, Moscow, NewDelhi, Paris, Prague, FaoPaulo, Seoul, Warsaw // Guintessence, 2013. - 500 р.). - М. ; Спб. ; К. ; Алматы ; Вильнюс : издательский дом «Азбука», 2013. - 500 с.

6. Новіков В. М. Кореляційні зв'язки між м'язовосуглобовою дисфункцією СНЩС та оклюзійними порушеннями при різних видах прикусів / В. М. Новіков, Ю. С. Лунькова // Проблеми екології та медицини. - 2011. - № 15 (3-4). - С. 120-122.

7. Шейко А.П. Взаємозв'язок оклюзійних порушень синдрому больової дисфункції / А. П. Шейко // Український стоматологічний альманах. - 2012. № 2. - C. 124.

8. Dodic S. The relationship of occlusal disharmonies and symptoms of temporomandibular disorders / S. Dodic, D. Stanisic-Sinobad, M. Vukadinovic // Srp. Arh. Celok. Lek. - 2006. - Vol.134, № 9. - P. 380-385.

9. The relationship between jaw injury, third molar removal, and orthodontic treatment and TMD symptoms in university students in Japan Text / R. Akhter, N. W. Hassan, R. Ohkubo [et al.] // J. Orofac. Pain.-2008.Vol. 22, № 1. - P. 50- 56. 